\title{
Epidermoid cyst of testis: A case report
}

\author{
Testiste epidermoid kist: Olgu sunumu
}

\author{
Seda Gün*a, Abdullah Açıkgöz ${ }^{b}$, Arzu Aydoğan Çilingira ${ }^{a}$ Can Aydın ${ }^{b}$ \\ ${ }^{a}$ Department of Pathology, Samsun Gazi State Hospital, Samsun, Turkey \\ ${ }^{b}$ Department of Urology, Samsun Gazi State Hospital, Samsun, Turkey
}

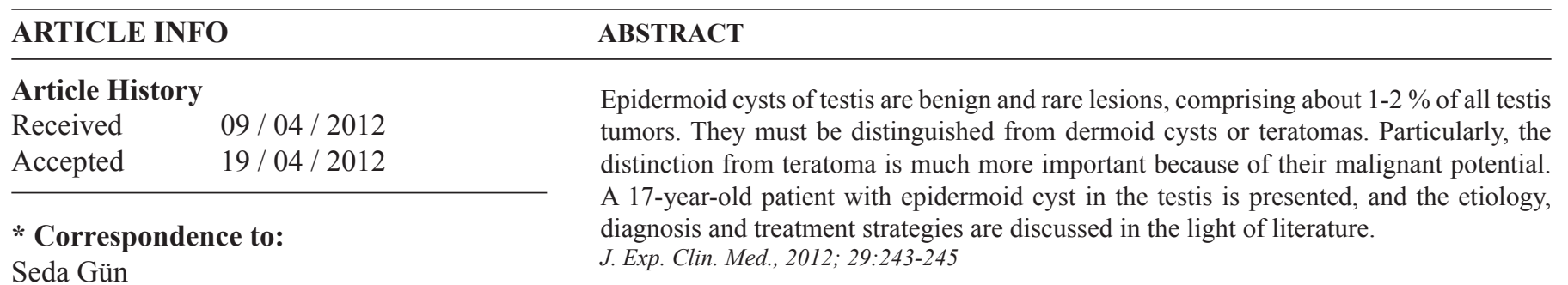

Samsun Gazi State Hospital,

Department of Pathology

Samsun, Turkey

e-mail: sakifgun@yahoo.com

Keywords:

Testis

Epidermoid cyst

Treatment

Diagnosis

Teratom

Dermoid cyst

\section{ÖZET}

Testisin epidermoid kistleri tüm testis tümörlerinin \% 1-2'sini oluşturan benign ve nadir lezyonlardır. Dermoid kistlerden veya teratomlardan ayırt edilmesi gerekir. Özellikle, malign potansiyeli nedeniyle teratomdan ayırımı daha fazla önemlidir. Onyedi yaşında testiste epidermoid kist olgusu sunulmuş, etyolojisi, tanı ve tedavi seçenekleri literatür eşliğinde tartışılmıştır.

J. Exp. Clin. Med., 2012; 29:243-245

\section{Introduction}

Epidermoid cysts of the testis are rare benign lesions and constitute $1-2 \%$ of all testicular neoplasms. Testicular epidermoid cysts usually present in the 2 nd and 4 th decades of life. Testicular epidermoid cysts are asymptomatic and are detected during the physical examination or in self-examination (Shah et al., 1981; Heidenreich et al., 1985; Malek et al., 1986). Clinically, it is difficult to differentiate them from malign tumors and they are often diagnosed after orchiectomy (Akpolat et al., 2004). A 17-year old patient with the testicular epidermoid cyst is presented and the etiology, diagnosis and treatment of the case are discussed.

\section{Case}

A 17-year-old male patient admitted to the urology outpatient clinics with the complaint of painless swelling which had been growing slowly for 3 months. In the physical examination, a hard, 10x10 mm mass with well-defined margins was identified in the lower pole of the right testis. The left testis was normal. In scrotal ultrasonography, a 14x13x10 hypoechoic mass with well-defined margins and calcifications was observed in the lower pole of the right testis (Fig.1).

Routine biochemical examinations revealed that patient's serum alpha-fetoprotein and beta-hCG levels were within normal limits. The patient underwent inguinal orchiectomy with the prediagnosis of malignant testis tumor. 


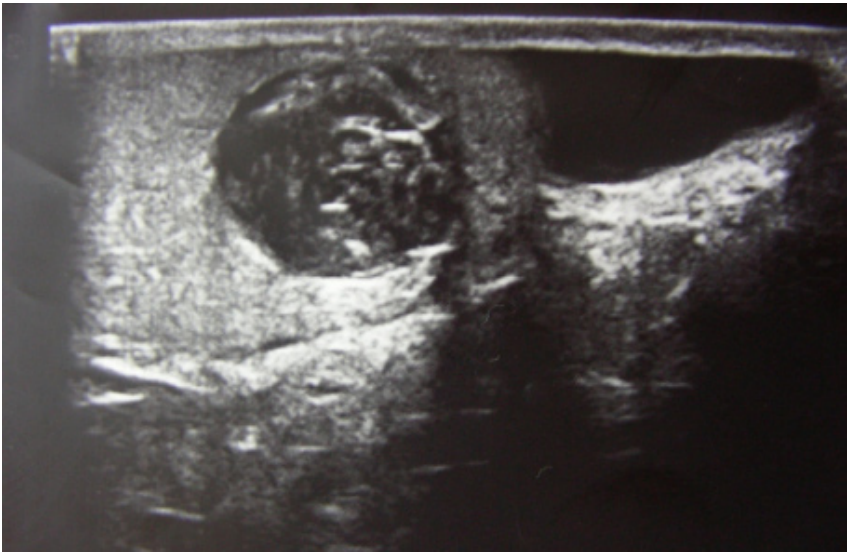

Fig. 1. Right testis ultrasonography: Hypoechoic mass with welldefined margin

Macroscopically, a $1.5 \mathrm{~cm}$-wide encapsulated cystic mass filled with yellow, paste-like material was identified in the section of $4.5 \times 3.5 \times 2.5 \mathrm{~cm}$ left orchiectomy material removed together with $9-\mathrm{cm}$ long spermatic cord. There was no pathological features in adjacent testicular parenchyma. Microscopic study identified a cystic lesion which was sharply delineated from the surrounding testis parenchyma. It was partially compressed, lined by stratified squamous epithelium with granular layer and filled with lamellar keratin material (Fig. 2).

The whole cyst was sampled. No skin appendages or elements of another germ leaf were detected. A limited number of atrophic tubules were observed in the neighboring testis parenchyma (Fig. 3). The epididymis and spermatic cord were normal. On the basis of these findings, the patient was diagnosed with epidermoid cyst.

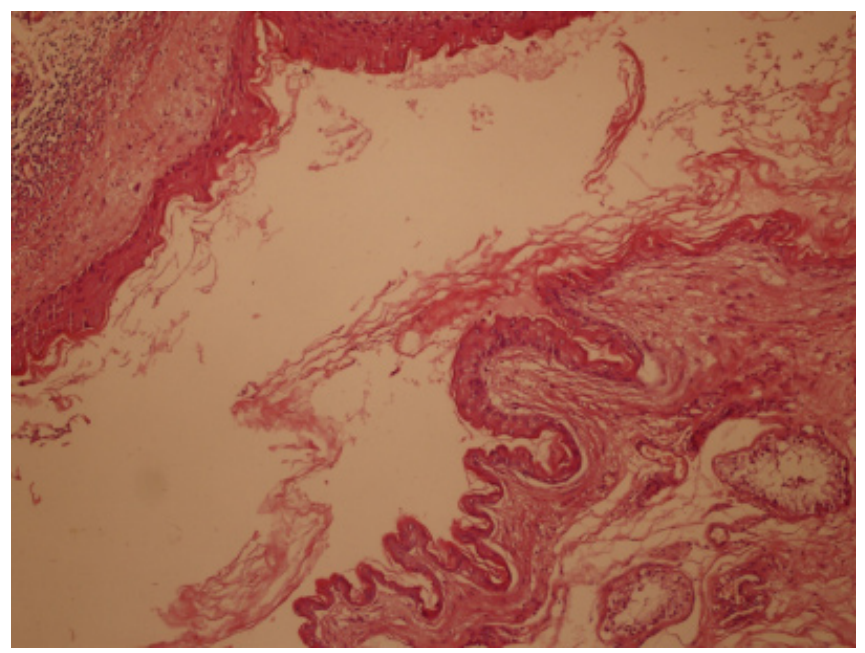

Fig. 2. The cyst wall lined with keratinizing squamous epithelium; its lumen is full of keratin material HE, x100.

\section{Discussion}

Testicular epidermoid cyst which accounts for $1-2 \%$ of the testicular cysts was first defined by Doctery and Prestly in 1942. Although the patients are in the range of 3-77, it is mostly observed in the 2nd and 4th decades of the life (Shah et al., 1981; Heidenreich et al., 1985; Malek et al., 1986; Akpolat et al., 2004). Its prevalence is slightly higher in the right testis than in the left (Nichols et al., 1984; Malek et al., 1986). It is usually a painless mass. It can be observed to-

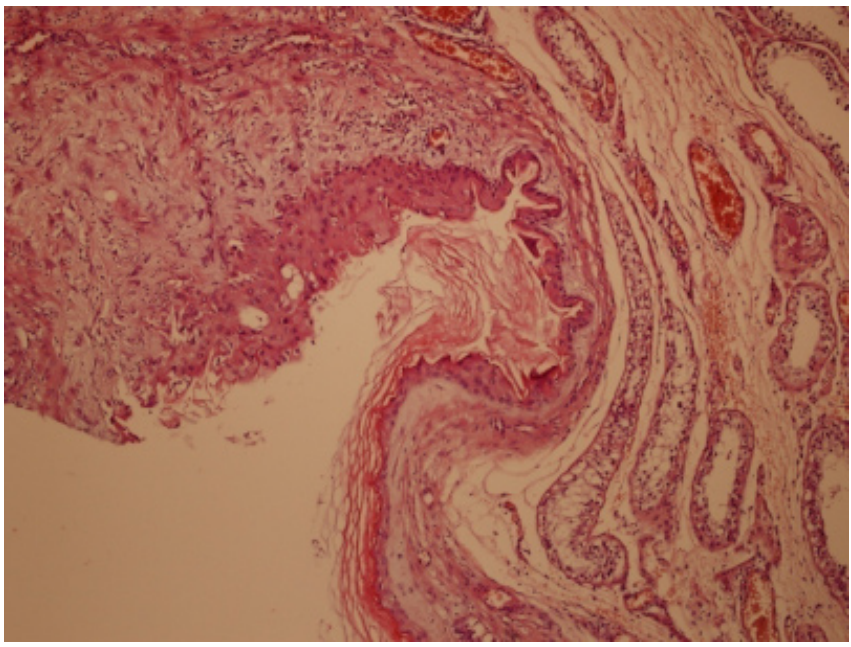

Fig. 3. The cyst separated from peripheral testicular parenchyma by fibrous capsule HE, x100.

gether with cryptorchidism (Gökden et al., 1994). Testicular epidermoid cysts can be bilateral or multiple (Loberant et al., 2011). Multiple cysts have been observed in 1 patient with cryptorchidism and Gardner's syndrome, and in 2 patients with Klinefelter's syndrome. Furthermore, accompanying carcinoid tumors were reported in one case. (Shah et al., 1981; Heidenreich et al., 1985; Malek et al., 1986). Cryptorchidism was not observed in our case.

Various theories have been suggested on the histogenesis of epidermoid cyst. Although rete testis is argued to originate from the squamous metaplasia of the seminiferous tubules and mesothelial inclusions, and from the scrotal primordial remnants, it is considered as benign monodermal teratoma (Behzatoğlu et al., 2001). Histopathological differentiation of benign epidermoid cyst from dermoid cyst or teratoma which has potential of malignancy is significant. Price established some histopathological criteria in diagnosing the testicular epidermoid cyst: (a) the cyst should be in the testis parenchyma, (b) lumen should include keratin, (c) the cyst wall composed of fibrous tissue should be lined with squamous epithelium, (d) there should be no teratomatous element, skin appendage or scar tissue in the cyst or neighboring parenchyma, (e) there should be no scar in the remaining parenchyma of the testis, (f) lipogranulomatous inflammatory reaction including local calcification areas can be observed, $(\mathrm{g})$ the wall of the cyst should be away from tunica albuginea (Moghe and Brady, 1999; Gupta et al., 2000). The findings in our case were consistent with the criteria.

The definitive preoperative diagnosis of testicular epidermoid cyst is not possible. Ultrasonographically, it is separated from testicular parenchyma by sharp margin and observed as hypoechogenous or hypo-hyperechogenic concentric rings surrounding the echogenic center. In magnetic resonance imaging, it is seen as a shield or as a lesion which looks like an ox eye (Loya et al., 2004).

Orchiectomy is an adequate and preferred treatment method for adults. However, testis-sparing surgery is performed on prepubertal patients (Heidenreich et al., 1995). Ellert et al. (2002) reported that the sensitivity and specifity of the frozen evaluation in distinguishing benignity and malignity is $100 \%$. The treatment in adults is more aggressive because $95 \%$ of the testis tumors diagnosed after puberty is malignant and there is no reliable method to differentiate them from 
preoperative teratomas. Furthermore, malignancy has been reported in 2 cases although their frozen section reports were negative (Behzatoğlu et al., 2001). In prepubertal children, sparing surgery along with intraoperative pathological frozen section examination is recommended because teratoma is considered benign in children. In recent years, if no germ cell neoplasm is identified after the excision of the cyst and the frozen section examination of 2 biopsies taken from adjacent parenchyma, sparing surgery are also recommended for the adult patients (Behzatoğlu et al, 2001; Loya et al., 2004). In our case, inguinal orchiectomy was preferred because the patient was adult and the suspicion of malignancy could not be conclusively eliminated.

In conclusion, the definitive diagnosis of testicular epidermal cysts is made histopathologically. Sparing surgery can be performed in adults if the history, physical examination, laboratory and radiological findings of the patient indicate a benign tumor, and in children, if the frozen section examination is also supportive. However, radical surgery is required in adults, particularly if there is suspicion of malignancy, because, whole cyst should be examined in such cases.

\section{REFERENCES}

Akpolat, N., Orhan, İ., Solmaz, Ö.A., 2004.Testicular epidermoid cyst: A case report. Turkish Journal of Urology. 30, $239-242$.

Behzatoğlu, K., Bahadır, B., Toktaş, G., Sarı, C., Ünlü, Y., 2001. Epidermoid cyst of testis (case report). The Turkish Journal of Pathology. 17, 87-89.

Ellert, A., Olbert, P., Hegele, A., Barth, P., Hofmann, R., Heidenreich, A., 2002. Accuracy of frozen section examination of testicular tumors of un certain origin. Eur. Urol. 41, 290-293.

Gökden, N., Canda, T., Göre, O., Yalçın, N., Kırkali, Z., Aktuğ, T., 1994. Epidermoid cyst of testis (two case). The Turkish Journal of Pathology. 10, 67-69.

Gupta, S.K., Golash, A., Thomas, J.A., Cochlin, D., Griffiths, D., Jenkins, B.J., 2000. Epidermoid cysts of the testis: The case for conservative surgery. Ann. Roy. Coll. Surg. 82, 411-413.

Heidenreich, A., Engelmann, U.H., Vietsch, H.V., Derschum, W., 1995. Organ preserving surgery in testicular epidermoid cysts. J. Urol. 153, $1147-1150$

Loberant, N., Bhatt, S., Messing, E., Dogra, V.S., 2011. Bilateral testicular epidermoid cysts. J. Clin. Imaging Sci. 1, 1-4.

Loya, A.G., Said, J.W., Grant, E.G., 2004. Epidermoid cyst of the testis: Radiologic-pathologic correlation. Radiographics. 24, $243-246$.

Malek, R.S., Rosen, J.S., Farrow, G.M., 1986. Epidermoid cyst of the testis: A critical analysis. Br. J. Urol. 58, 55-59.

Moghe, P.K., Brady, A.P., 1999. Ultrasound of testicular epidermoid cysts. B.J.R. 72, 942-945.

Nichols, J., Kandzarı, S., Elyaderan1, M.K., Rochlani, S., 1984. Epidermoid cyst of testis: A report of 3 cases. J. Urology. 133, $286-287$.

Shah, K.H., Maxted, W.C., Chun, B., 1981. Epidermoid cysts of the testis: A report of three cases and an analysis of 141 cases from the world Literature. Cancer. 47, 577-582. 